\title{
Density, abundance and group size of river dolphins (Inia geoffrensis and Sotalia fluviatilis) in Central Amazonia, Brazil
}

\author{
H.J. Pavanato ${ }^{1,2}$, C. Gomez-Salazar ${ }^{3,4}$, F. Trujillo ${ }^{3}$, D. Lima ${ }^{1,5}$, M. Paschoalini ${ }^{1,6}$, N. Ristau ${ }^{1,7}$ And M. Marmontel $^{1}$ \\ Contacte-mail: hpavanato@maths.otago.ac.nz
}

\begin{abstract}
A boat-based survey was conducted in the Tefé river and lake (Brazil) in December 2013, during the transitional water period. A combination of strip-width transects parallel to the river, lake-margins and confluences, and cross-channel line transects in the lake, were used to cover a total distance of 670 linear kilometres of the dolphins' habitat. A total of 383 groups of Amazon river dolphin and 124 groups of tucuxi were observed. Group size, density and abundance estimates were obtained per species and habitat (tributary, lake-margin and confluence). Group sizes ranged from one to six individuals for the Amazon river dolphin and from one to eight individuals for the tucuxi. The abundance of river dolphins was higher for the Amazon river dolphin $(911, \mathrm{CV}=0.15)$ than the tucuxi $(511, \mathrm{CV}=0.26)$. Higher densities were found in the lake-margin and tributary for the Amazon river dolphin and in the confluences for the tucuxi. Lake-margins, confluences and tributaries are therefore proposed as critical habitats for the conservation of river dolphins in central Amazonia. The Tefé lake is identified as an area of concern due to a high number of human stressors such as boat traffic, fishing and habitat degradation.
\end{abstract}

KEYWORDS: ABUNDANCE ESTIMATES; HABITAT; SURVEY-VESSEL; MONITORING; SOUTHERN HEMISPHERE; SOUTH AMERICA

\section{INTRODUCTION}

The Amazon river dolphin (Inia geoffrensis, Blainville 1817) and the tucuxi (Sotalia fluviatilis Gervais and Deville, 1853), are widely distributed in the Amazon, Orinoco and Tocantins river basins of South America (Best and da Silva, 1993; Hrbek et al., 2014; Santos et al., 2012). The Amazon river dolphin is listed as 'Endangered' by the International Union for Conservation of Nature (IUCN) Red List of Threatened Species (da Silva et al., 2018) and the National List of Brazilian Fauna Threatened with Extinction (Brazilian Ministry of the Environment, 2014); the tucuxi is listed as 'Data Deficient' in both of the lists primarily due to the lack of data and associated assessments to evaluate the risk of population decline (Secchi, 2012). Lack of data is of concern, particularly because river dolphins are facing increasing human threats such as negative interaction with fisheries, population isolation by dams, bio-contamination by heavy metals (mining) and their illegal harvest for use as bait in fisheries for the piracatinga catfish, Calophysus macropterus (Gómez et al., 2008; Hoyt, 2005; Iriarte and Marmontel, 2013; Trujillo et al., 2010). Furthermore, the Action Plan for South American River Dolphins 2010-20 (Trujillo et al., 2010) recommended that density and abundance estimates be generated to evaluate and monitor the status of dolphin populations and to prioritise conservation and management actions, particularly in areas with absence of information.

This study provides estimates of density and abundance of river dolphins in a sub-basin of the Amazon river in central Amazonia as part of an initiative to strengthen an existing network of researchers and managers known as the South American River Dolphin Protected Area Network (SARDPAN). The overarching goal of this study is to contribute to the evaluation and monitoring of the conservation status of river dolphins in South America. The research reported here constitutes the first estimate of density and abundance of river dolphins for the Tefé river and lake.

\section{METHODS}

\section{Study area}

Boat-based surveys were conducted in the Tefé lake and river (a tributary of the Solimões river), a narrow river and lake system of central Amazonia ( $\left.3^{\circ} 21^{\prime} 0.35^{\prime \prime} \mathrm{S}, 64^{\circ} 42^{\prime} 54.04^{\prime \prime} \mathrm{W}\right)$, see Fig. 1. The Tefé river is a narrow tributary whose headwaters rise in lowlands dominated by sandy soils (Goulding et al., 2003; Sioli, 1984). The tributary and lake are formed by black waters that are poor in nutrients, with high concentrations of organic compounds leading to an acidic $\mathrm{pH}$ (Goulding et al., 2003; Sioli, 1984). The lake has low water quality near the town of Tefé because of household sewage and solid waste disposal (Borges et al., 2013). Fisheries activity is widely spread in the Tefé river and lake (Barthem, 1990), contributing to almost $30 \%$ of the fish landed in the town of Tefé (Ilha, pers. comm.).

\section{Sampling protocol}

A regional boat-decker, navigating at an average speed of $12 \mathrm{kmh}^{-1}$, was used to conduct a survey from 3-11 December 2013, during the transitional water period at the beginning

\footnotetext{
${ }^{1}$ Research Group on Amazonian Aquatic Mammals, Mamirauá Institute for Sustainable Development, Estr. do Bexiga No. 2584, Tefé, Brazil.

${ }^{2}$ Department of Mathematics and Statistics, University of Otago, PO Box 56, Dunedin 9016, Otago, New Zealand.

${ }^{3}$ Omacha Foundation, Calle 86A No. 23-38, Bogota, Colombia.

${ }^{4}$ Biology Department, Dalhousie University, Halifax, Nova Scotia B3H 4J1, Canada.

${ }^{5}$ Laboratory of Mastozoology, Institute of Scientific and Technological Research of the State of Amapá, Rod. Juscelino Kubitschek km. 10, Macapá, Amapá, Brazil.

${ }^{6}$ Laboratory of Behavioral Ecology and Bioacoustics, Federal University of Juiz de Fora, R. José Lourenço Kelmer, Juiz de Fora, Minas Gerais, Brazil.

${ }^{7}$ Biological Science Department, University Federal of Maranhão, Cidade Universitária Paulo VI cx. Postal 09, São Luís, Maranhão, Brazil.
} 


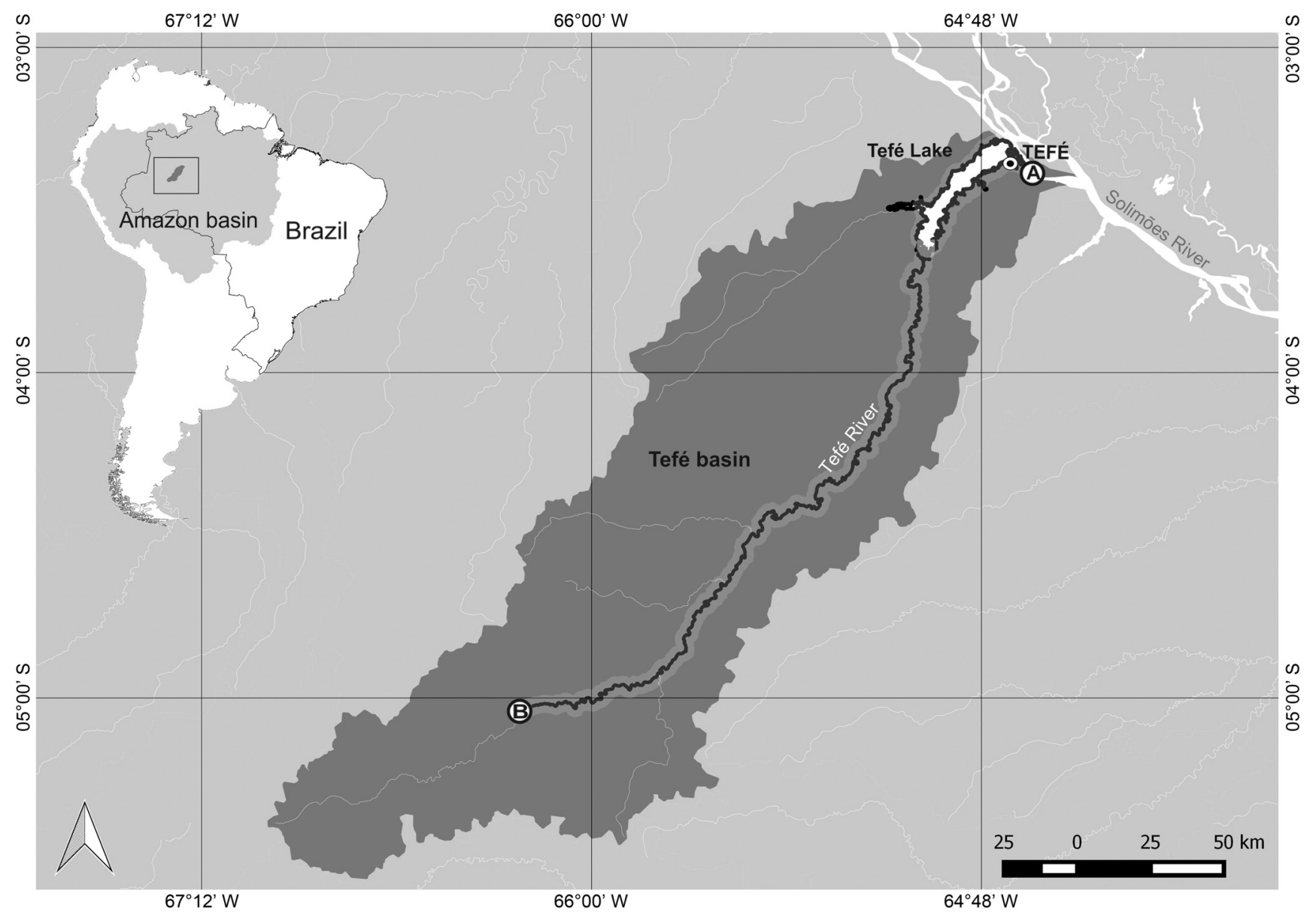

Fig. 1. Map of Central Amazonia (light grey) specifying the sub-basin of Tefé river (dark grey) and Tefé town. Point A indicates the survey starting location at the confluence between the Tefé lake and the Solimões river and point B the survey end location at the Tefé river.

Table 1

Definition of habitat types surveyed during December 2013 in central Amazonia

\begin{tabular}{|c|c|c|}
\hline Habitat type or stratum & Location in this study & Definition \\
\hline Tributary & Tefé river & $\begin{array}{l}\text { Small and medium size rivers with maximum width of } 400 \mathrm{~m} \text { (Gomez-Salazar et al., 2012a). } \\
\text { Most of the small blackwaters rivers are concentrated in the central Amazon, just as Tefé } \\
\text { river (Goulding et al.,2003). }\end{array}$ \\
\hline Confluence & Tefé lake and Solimões river & $\begin{array}{l}\text { Connection areas between small or large rivers and lakes with others, including channels. } \\
\text { May or may not present a mix of waters (Martin et al., 2004, Gomez-Salazar et al., 2012a). } \\
\text { The confluence between Tefé lake and Solimões river is an example of black and white } \\
\text { waters mixing. }\end{array}$ \\
\hline \multirow[t]{3}{*}{ Lake } & Tefé lake: General & $\begin{array}{l}\text { Can present oval, elongated or dendritic shapes and shallow waters with maximum depth } \\
\text { ranging from } 6-12 \mathrm{~m} \text { in the high-water level. Large lakes, such as Tefé, are connected to } \\
\text { rivers most of the time through small channels (Junk et al., 2012). }\end{array}$ \\
\hline & Tefé lake: Margin area & $\begin{array}{l}\text { Area of the lake with a width of } 200 \mathrm{~m} \text { from the margin to the channel (Martin et al., 2004, } \\
\text { Gomez-Salazar et al., 2012a). }\end{array}$ \\
\hline & Tefé lake: Channel area & $\begin{array}{l}\text { Area of the lake excluding the area of lake-margin, i.e., channel further away than } 200 \mathrm{~m} \text { of } \\
\text { the margin in any perimeter of the lake (Martin et al., 2004, Gomez-Salazar et al., 2012a). }\end{array}$ \\
\hline
\end{tabular}

of the flooding season (between 'low' and 'high' water levels).

River dolphins' habitat comprises rivers, channels, lakes and confluences, all of which have diverse characteristics (Table 1). They are distributed differentially amongst these various habitats, with densities generally higher at the river margins, confluences and lakes (Gomez-Salazar et al., 2012a; Martin and da Silva, 2004; Martin et al., 2004). Recognising the need to take this into account in the sampling design, data collection as well as data analysis were carried out by means of stratification (Buckland et al., 2001;
2004). A combination of strip and cross-channel line transect field protocols were implemented (Gomez-Salazar et al., 2012a; Martin and da Silva, 2004; Vidal et al., 1997). Crosschannel line transects were conducted by crossing the lake from one margin to another in a zigzag pattern. Strip-width transects of $200 \mathrm{~m}$ or less (depending on the river width) were conducted parallel to the margin of the lake and the tributary, where the distance to the shore was controlled using a laser range finder. Only strip transects were conducted in the Tefé river due to the limited width of this tributary (mean width of $152 \mathrm{~m})$. 
Two independent platforms were present, each $7.3 \mathrm{~m}$ above water level (Gomez-Salazar et al., 2012a; Laake and Borchers, 2004). The first platform was located at the front of the boat (forward platform), and the second platform at the back, facing the opposite direction (rear platform). There were three observers and one data recorder on each platform, an additional effort data recorder in the forward platform and a 'referee' transiting between both platforms. The observers actively searched for the river dolphins from $0^{\circ}$ (trackline) to $90^{\circ}$ on each side of the platform. For each sighting, the following information was collected: geographic position, species, group size, presence of calves, distance from the dolphins to the margin (collected only for strip transects), angle of the observer to the dolphins and distance from the observer to the dolphin group. Distances to the dolphins and from the dolphins to the margins were estimated by naked eye by observers with previous experience with the survey method described above (CG-S and FT).

Sighting data from both platforms were integrated into a single data sheet at the end of the survey and the correspondence between the dolphins detected by the forward and rear platform was determined (i.e. whether a sighting from the rear platform was a confirmation of one from the front platform or a new detection). This was based on the judgment of the referee regarding time of the sightings, side, angle, species and group size (i.e. whenever the referee had not been able to track the group in real time from the forward to the rear platform).

Following Gomez-Salazar et al. (2012a), environmental conditions were recorded every 30 minutes and included river state ( 0 to 3 , increasing turbulence scale), glare ( 0 to 3 , increasing intensity scale) and visibility ( 1 to 4,1 being poor and 4 excellent).

\section{Density estimates: strip transects}

Density of river dolphins for each habitat $i$ (tributary, lakemargin, confluence) were obtained based on a HorvitzThompson-like estimator:

$$
\hat{D}_{i}=E(s) \frac{\hat{D} g_{i}}{w \hat{g}(0)^{\prime}}
$$

where $E(s)$ is the mean group size, $w$ is the transect width (truncated at $200 \mathrm{~m}$ or mean width when the distance across the tributary was $<200 \mathrm{~m})$ and $\hat{g}(0)$ is the detection probability on the transect line.

River dolphins have been found to be distributed according to a gradient with higher densities closer to the margin in the first $50 \mathrm{~m}$ lessening towards the river channel up to $200 \mathrm{~m}$ out (Gomez-Salazar et al., 2012a; Martin et al., 2004). Considering that detection probability decreases with distance, a conflict between density and detection variation may occur. For this reason, corrections for undetected clusters in the $200 \mathrm{~m}$ strip-width transects were incorporated $(P 1$ and $P 2$ ) by using a detection function fitted for the crosschannel line transects (Gomez-Salazar et al., 2012a). Therefore, density of clusters $\left(\hat{D} g_{i}\right)$ is defined as:

$$
\hat{D} g_{i}=\frac{E R_{i(0-50)}}{P_{2}}+\frac{E R_{i(50-100)}}{P_{1}}+\frac{E R_{i(100-150)}}{P_{1}}+\frac{E R_{i(150-200)}}{P_{2}}
$$

Where $E R$ is the mean encounter rate by transect, $P 1_{\text {Amazon river dolphin }}=0.955$ and $P 1_{\text {Tucuxi }}=0.994$ are the detection probabilities between $0-50 \mathrm{~m}$ from the transect line (i.e. $50-$ $100 \mathrm{~m}$ or $100-150 \mathrm{~m}$ from the margin), and $P 2$ $=0.523$ and $P 2_{\text {Tucuxi }}=0.675$ are the detection probability between $50-100 \mathrm{~m}$ from the transect line (i.e. $0-50 \mathrm{~m}$ or $150-$ $200 \mathrm{~m}$ from the margin).

The $\hat{g}(0)$ was estimated with the Petersen estimator:

$$
\hat{g}(0)=1-\frac{n_{\text {rear new }^{2}}}{n_{\text {rear }}}
$$

Where $n_{\text {rear }}$ is the number of river dolphins detected by the rear platform and $n_{\text {rear new }}$ is the number of dolphins detected by the rear platform which were not detected by the forward platform.

Finally, abundance was derived from density as:

$$
\hat{N}_{i}=\hat{D}_{i} A_{i}
$$

Where $A_{i}$ is the size of the area surveyed, calculated using Geographic Information Systems (GIS). For tributary and lake-margin habitats, the areas were calculated as the perimeter of the Tefé river and lake multiplied by the average strip width of 152 and $200 \mathrm{~m}$ respectively. For lake-channel habitat, the area resulted from the difference between the total area of the lake and the area of the lake-margin. For confluence, the width of each confluence was multiplied by the transect length, and then summed to obtain the total area.

The variances of encounter rates were derived empirically, the variances of the detection probability ( $P 1$ and $P 2)$ were estimated following Gomez-Salazar et al. (2012a) and the variances of $\hat{g}(0)$ calculated through the delta method (Seber, 1982). These were used to compute the final variance and correspondent standard deviation (SD) and coefficient of variation $(\mathrm{CV})$.

\section{Density estimates: line transects}

It was expected that density estimates of river dolphins in the lake-channel area would be obtained by fitting detection probability models to perpendicular distance data using conventional line transect sampling methods (Buckland et al., 2001). However, only 7 and 2 sightings were recorded for the Amazon river dolphin and the tucuxi respectively, an insufficient sample to properly estimate detection probability (Buckland et al., 2001). For populations that occur in clusters, such as in the present study, the sample size should be larger $(\sim 60-80)$ to accurately estimate abundance of individuals (Buckland et al., 2001). For this reason, the results in the lake-channel were omitted and only the encounter rates were presented in order to compare with relative densities estimated for other habitats. The majority of river dolphins are found in areas closer to the river bank (Gomez-Salazar et al., 2012a; Martin et al., 2004), and thus, it is not expected that omitting estimates from cross-channel line transects will have a large impact in the overall abundance estimate of dolphins for this region.

\section{RESULTS}

A total of 590 and 80 linear kilometres of sampling effort were conducted using strip and cross-channel line transects respectively, with a total of 383 sightings of Amazon river dolphins and 124 sightings of tucuxis recorded. Overall, the transects were surveyed during good sighting conditions: 
Table 2

Area of stratum (A) $\left(\mathrm{km}^{2}\right)$, mean group size $E(s)$ with correspondent standard deviation $(S D(s))$, number of sightings $(n)$, mean encounter rate by transect $(E R)$, abundance $(\widehat{N})$ and density $(\widehat{D})\left(\right.$ ind $\mathrm{km}^{-2}$ ) with correspondent standard deviation (SD) and coefficient of variation $(\mathrm{CV})$ for Amazon river dolphin (I. geoffrensis) and tucuxi (S. fluviatilis) by stratum.

\begin{tabular}{|c|c|c|c|c|c|c|c|c|c|c|c|c|c|c|c|c|c|}
\hline \multirow[b]{2}{*}{ Habitat } & \multicolumn{9}{|c|}{ Amazon pink dolphin } & \multicolumn{8}{|c|}{ Tucuxi } \\
\hline & $\mathrm{A}$ & $E(s)$ & $S D(s)$ & $n$ & $E R$ & $\widehat{N}$ & $\widehat{D}$ & SD & $\mathrm{CV}$ & $E(s)$ & $S D(s)$ & $n$ & $E R$ & $\widehat{N}$ & $\widehat{D}$ & SD & $\mathrm{CV}$ \\
\hline Tributary & 104 & 1.44 & 0.70 & 395 & 0.72 & 582 & 5.59 & 0.99 & 0.18 & 2.32 & 1.49 & 140 & 0.38 & 210 & 2.01 & 2.58 & 1.28 \\
\hline Lake-margin & 76 & 1.40 & 0.73 & 139 & 0.65 & 327 & 4.28 & 1.13 & 0.26 & 2.35 & 1.44 & 122 & 0.73 & 290 & 3.79 & 1.71 & 0.45 \\
\hline Lake-channel & 328 & 1.43 & 0.79 & 10 & 0.28 & - & - & - & - & 1 & 0.00 & 2 & 0.08 & - & - & - & - \\
\hline Confluence & 1.2 & 1.67 & 1.03 & 10 & 0.91 & 2 & 1.54 & 1.03 & 0.67 & 3.2 & 1.90 & 16 & 1.60 & 9 & 9.08 & 1.10 & 0.12 \\
\hline Overall** & 509.20 & 1.48 & - & 554 & 0.64 & 911 & 3.80 & - & 0.15 & 2.22 & - & 280 & 0.70 & 511 & 4.96 & - & 0.26 \\
\hline
\end{tabular}

* The values are rounded for two decimal places to fit in the table. Therefore, the multiplication of density and area does not result exactly in the abundance.

** The overall estimates of $E(s), E R$ and $\widehat{D}$ correspond to the mean among habitats.

$100 \%$ during low turbulence (levels 0 and 1), $84 \%$ during minimum glare (levels 0 and 1 ) and $68 \%$ during good and excellent visibility.

Group size ranged from one to six individuals for Amazon river dolphin and from one to eight for tucuxi. Differences in group size across habitats were not observed for both species (Kruskal Wallis test, $\alpha=0.05$ ). Almost all animals present were detected: $\hat{g}(0)$ was estimated at $0.99(\mathrm{CV}=$ $0.002)$ for the Amazon river dolphin and $0.99(\mathrm{CV}=0.003)$ for tucuxi. The highest density of Amazon river dolphins was found in the tributary $\left(5.85\right.$ ind $\left.\mathrm{km}^{-1}, \mathrm{SD}=0.99\right)$, while the lowest density was found in the confluences $\left(1.54\right.$ ind $\mathrm{km}^{-1}$, $\mathrm{SD}=1.03$; Table 2 ). Conversely, the tucuxi's highest density was in the confluences $\left(9.03\right.$ ind $\left.\mathrm{km}^{-1}, \mathrm{SD}=1.29\right)$, followed by the lake-margin habitat ( 3.77 ind km$\left.^{-1}, \mathrm{SD}=1.71\right)$ (Table 2). Overall, the abundance of river dolphins in the Tefé riverlake system was higher for Amazon river dolphin (911, $\mathrm{CV}=0.15)$ than tucuxi $(511, \mathrm{CV}=0.26)($ Table 2).

\section{DISCUSSION}

This study provides a benchmark for river dolphin abundance estimates in the Tefé river and lake. Group size, density and abundance were explored in different habitats to enable a comparison among them and with other studies.

Group sizes of both species of river dolphins (ranging from 1 to 8 ) were consistent with previous studies in other regions of Amazonia (Gomez-Salazar et al., 2012b; Martin et al., 2004). Differences in group size across habitats were not identified. As stated by other studies (Gomez-Salazar et al., 2012b; Martin et al., 2004), these differences might arise from repeated surveys conducted in different seasons. Repeated surveys could for example identify the behavioural responses of river dolphins to freshwater floods.

The preference of river dolphins for lakes and confluences instead of narrow rivers has been reported in other regions of Amazonia, as these areas have higher productivity compared with other habitats (Aliaga-Rossel, 2002; GomezSalazar et al., 2012b; Martin et al., 2004; McGuire and Wienemiller, 1998). For instance, the mixing of black and white waters in the confluence between the Japurá and Solimões rivers (an area adjacent to our study area) has also been reported as a preferred habitat for tucuxi (Martin et al., 2004). Similarity of features is likely to explain the high density of tucuxi in the confluence between the Tefé lake and Solimões river.

Although confluences represent less than $1 \%$ of the proportion of the total study area, this habitat is particularly important in Amazonia for the movement of aquatic life between rivers, tributaries and lakes during and after freshwater floods (Barthem and Goulding, 1997; Fernandes, 1997; Henderson, 1990). Every year during the highwater period, an area of approximately $170,000 \mathrm{~km}^{2}$ in the Amazon is inundated, forming the floodplains (Hamilton and Lewis, 1990). Seasonal freshwater floods enhance the total aquatic productivity in the Amazon and trigger the migration of fish and dolphins between habitats (Barthem and Goulding, 1997; Lewis et al., 2000; Martin and da Silva, 2004).

Contrary to the tucuxi, densities of Amazon river dolphins were the highest in the Tefé river (tributary). Amazon river dolphins have morphological adaptations (e.g. flexible bodies, small dorsal fins and large pectoral fins) that allow them to exploit narrow areas with limited water depth without getting stranded (Martin and da Silva, 2004). This may explain the higher density of Amazon river dolphins in the tributary, and the higher density of tucuxi in habitats that are easier to navigate (i.e. confluences and lakes) during the present study due to the season when the study took place.

\section{Comparing monitoring efforts in Amazonia}

Density and population size of river dolphins in South America have been estimated from surveys conducted in small areas using varied methodologies. Earlier surveys were mainly focused on obtaining encounter rates instead of densities and abundance estimates (da Silva, 1994; Herman et al., 1996; Kasuya and Kajihara, 1974; Layne, 1958; Meade and Koehnken, 1991; Pilleri and Gihr, 1977; Trujillo, 2000). More recent surveys have been conducted using standardised sampling methods (Aliaga-Rossel, 2002; Leatherwood, 1996; Martin and da Silva, 2004; Martin et al., 2004; McGuire, 2002; Utreras, 1996; Vidal et al., 1997). However, these latter studies have differences in sighting protocols (e.g. number of observers), analysis (e.g. assumptions about $g(0)$, corrections by the detection probability as a function of perpendicular distances), and the season surveyed. Consequently, caution should be applied when comparing results across areas and studies. Here, the sampling and analytical methods proposed by Gomez-Salazar et al. (2012a) were followed, which allowed for a preliminary and relatively simple comparison with density estimates reported in other areas of Amazonia (Figs 2 and 3).

The density of the Amazon river dolphin in the Tefé river was higher than the densities reported in tributaries located in Bolivia, Venezuela, Colombia and Ecuador, and similar to one of the highest densities ever reported - in a Peruvian 


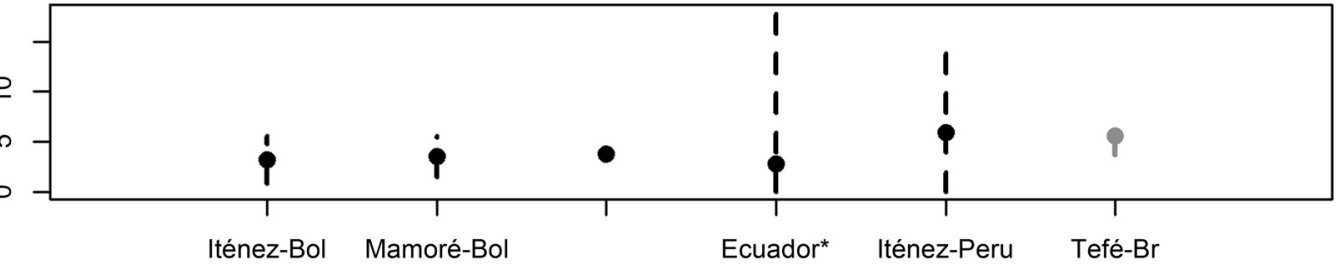

Tributary
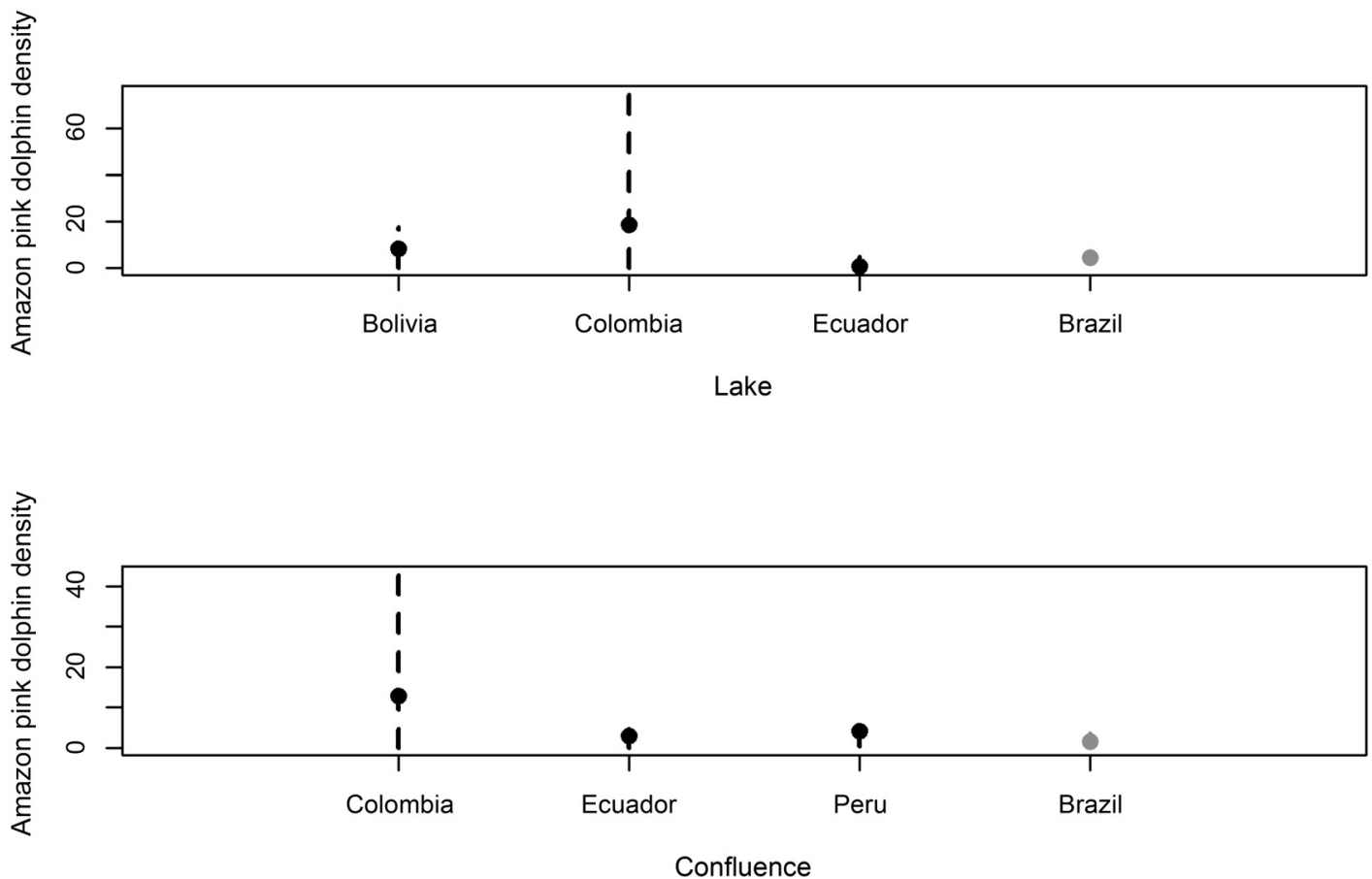

Fig. 2. Density of $I$. geoffrensis estimated in tributaries, lakes and confluences of Colombia, Ecuador, Peru and Bolivia (from Gomez-Salazar et al. (2012a) (black) and Brazil (grey). Dots represent the mean estimates and dashed lines the standard errors. *Refers to Cuyabeno, Yasuni, Lagartococha and Aguarico rivers.

tributary (Gomez-Salazar et al., 2012a). This suggests that the Tefé river, together with the Pacaya Samiria Reserve in Peru, the Mamirauá Sustainable Development Reserve in Brazil, and the Iténez and Mamoré rivers in Bolivia, are hotspots for the Amazon river dolphin at a regional scale (hotspots of river dolphins were previously defined and identified as locations with the highest density estimates of dolphins in South America; Gomez-Salazar et al., 2012a).

Conversely, the density estimates of the Amazon river dolphin reported in the Tefé lake and in the confluence were smaller than those obtained in other countries, being only comparable to the low densities of Ecuador (Gomez-Salazar et al., 2012a). Further surveys which take into account seasonality might clarify the importance of the Tefé lake for Amazon river dolphins.

For tucuxi, the density was smaller than estimates reported in rivers of Colombia and higher than in rivers of Ecuador (Gomez-Salazar et al., 2012a). Conversely, density at confluences was similar to that estimated in Peru (GomezSalazar et al., 2012a). Nevertheless, caution is warranted when interpreting these results due to the large CVs associated with the density estimates.

It is also important to highlight that because the abundance of river dolphins in the lake-channel was not estimated due to the small number of detections in this habitat, the overall abundance in the Tefé lake will be negatively biased to an unknown extent. The low abundance of river dolphins in the lake-channel corroborates other studies in which the encounter rates in lake or river channels are usually low (Gomez-Salazar et al., 2012a; Martin et al., 2004).

\section{Human activities impacting river dolphin populations in the Tefé lake}

Although density estimates for river dolphins in lake-margin habitats are usually the highest in other areas of Amazonia, this is not the case in the Tefé lake. Due to its proximity with the city of Tefé (human population of 62,662 in 2014), a variety of potentially harmful (to dolphins) human activities take place within the lake region, including fisheries, logging and riverine vessel traffic. A systematic survey reported 11 Amazon river dolphin and 4 tucuxi carcasses in the Tefé lake in 2013 (unpublished data). Taking into account the abundance point estimate provided in this study, these mortalities represent approximately $1.15 \%$ of the Amazon river dolphin and $0.8 \%$ of the tucuxi population being removed from the Tefé lake in a single year. Evidence of 

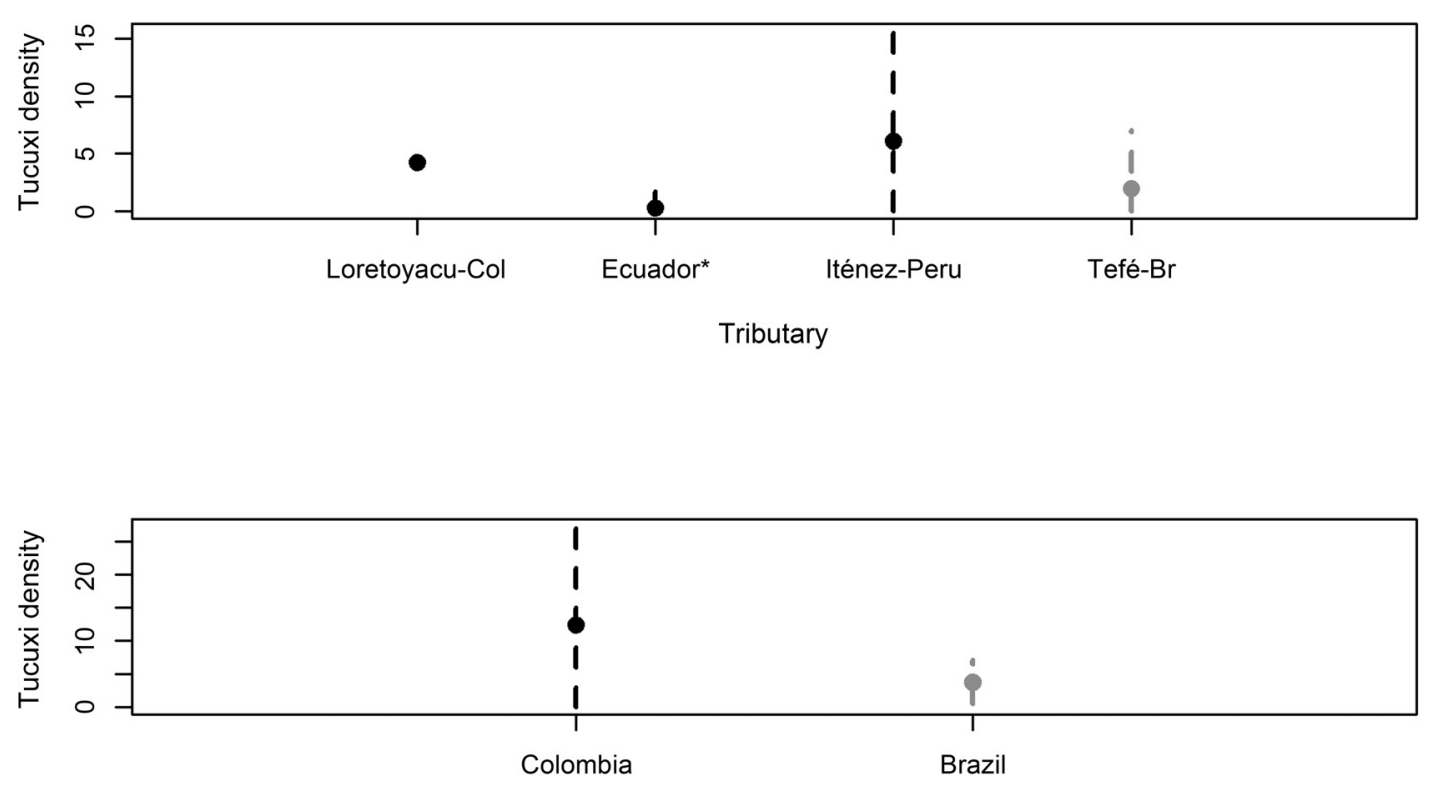

Lake

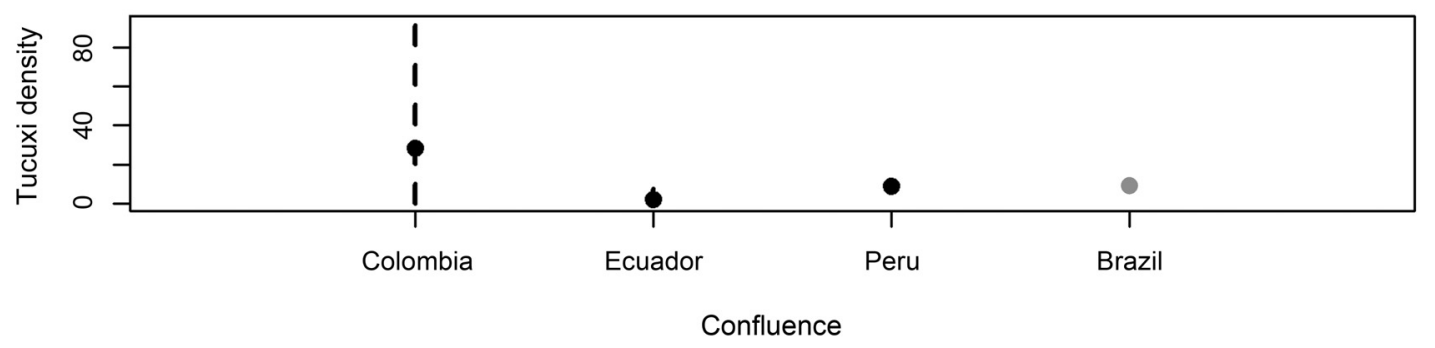

Fig. 3. Density of $S$. fluviatilis estimated in tributaries, lakes and confluences of Colombia, Ecuador and Peru (from GomezSalazar et al. (2012a) (black) and Brazil (grey). Dots represent the mean estimate and dashed lines the standard errors. *Refers to Cuyabeno, Yasuni, Lagartococha and Aguarico rivers.

interaction with fisheries based on possible marks of gillnets (entanglement) and of intentional killing (spear and axe marks) were observed in 55\% of the carcasses (Santos et al., 2014). Another threat to these populations includes habitat degradation, in particular chemical pollution. The city of Tefé does not have basic sanitation services and as a consequence, household sewage, wastewater and solid waste have been released into Tefé lake (Borges et al., 2013). The poor water quality of the lake may explain findings of abscesses in the river dolphins necropsied which may be due to infectious diseases such as tuberculosis, pneumonia, golf ball disease and others (Bueno, pers. comm.). It is important to highlight that the number of carcasses reported probably represent a minimum mortality value as they do not account for unobserved records.

Of most serious concern is the decline in apparent survival of Amazon river dolphins for the past ten years in an area adjacent to the Tefé lake (Mintzer et al., 2013). This decline has been attributed to the illegal harvesting of dolphins to be used as bait for the piracatinga catfish fishery. Moreover, the harvest rates reported seemed to exceed conservation limits and may be unsustainable (Mintzer et al., 2013). In response, the Brazilian government has banned the commercial capture of the piracatinga catfish for five years starting on January 2015. There is no sign that this illegal harvesting is currently occurring in the Tefé river-lake system, although purchase, storage and disposal of piracatinga catfish still occur in the town of Tefé (Botero-Arias et al., 2014).

In addition, disturbance due to elevated levels of noise generated from human activities can cause sub-lethal impacts (New et al., 2013; NRC, 2005; Pirotta et al., 2014). The potential impacts of noise on river dolphin populations in general have not as yet been studied (e.g. possible displacement from important habitats and foraging disruption), and noise exposure is potentially an additional human stressor to river dolphins in the Tefé lake.

Overall, human activities in South America riverine areas are increasing and some of these activities are causing lethal and/or sub-lethal impacts on river dolphin populations. The local and regional magnitude of these potentially cumulative impacts is not as yet fully understood.

\section{FINAL REMARKS AND RECOMMENDATIONS}

This study represents the first attempt at a standardised monitoring programme with the goal of assessing population trends of Amazon river dolphins and tucuxi in the Tefé riverlake system. Confluences, which are important areas for river connectivity, as well as lake-margin areas, had the highest density estimates of tucuxis. Conversely, the Tefé river had some of the highest density estimates ever reported for 
the Amazon river dolphin. Therefore, we propose these confluences and Tefé lake as areas of high priority for tucuxi conservation at a local scale, and the Tefé river as an important area for the conservation of the Amazon river dolphin at both local and regional scales.

The relatively low density estimates of river dolphins in the Tefé lake, as well as the high number of increasing human activities observed in this study and in the Amazon as a whole, should be further investigated. Estimating and monitoring the potential lethal and sub-lethal impacts of human activities on river dolphin populations is recommended as a process to be undertaken in parallel to efforts to monitor river dolphin distribution and abundance. This information is fundamental to informing conservation priorities in the region.

As previously reported, repetitive surveys conducted in riverine areas using comparable methodology are required to investigate how seasonality, habitat, and other potential environmental and human variables drive variation in the density of river dolphins. However, due to funding constraints, repetitive surveys cannot be always implemented in these remote areas. In those cases, it has been proposed to survey areas during the transitional water periods, where most of the habitat types are available (e.g. channels are not completely dry and lakes are still connected to the main rivers) to make studies more comparable (Gomez-Salazar et al., 2012a).

This study reports on current efforts, which are being replicated in several rivers of South America, to improve knowledge on river dolphin population parameters. Equally important, these studies are being designed with the goal of strengthening SARDPAN and enhancing capacity building in South America.

\section{ACKNOWLEDGMENTS}

We thank André Bastos, Beatriz Calera, Damaris Bonfim, Luzivaldo dos Santos, Mariana Santos, Marília de Lima and Sandro Azevedo for their work as observers in the field. Thank you also to Eliane Oliveira from Mamirauá Institute for Sustainable Development for mapping information. We are grateful to Alexandre Zerbini, Marcela Portocarrero-Aya and one anonymous reviewer for their valuable suggestions to improve the manuscript. This study was funded by Petrobras through the Petrobras Environmental Program and Ministério da Ciência, Tecnologia e Inovação (MCTI), with the support of Omacha Foundation, World Wildlife Fund Colombia and Whitley Fund for Nature. The Conselho Nacional de Desenvolvimento Científico e Tecnológico (CNPq) provided a scholarship to the first author who worked under the guidance of the last.

\section{REFERENCES}

Aliaga-Rossel, E. 2002. Distribution and abundance of the river dolphin (Inia geoffrensis) in the Tijamuchu River, Beni, Bolivia. Aquatic Mammals 28(3): 312-23.

Barthem, R.B. 1990. Ecologia e pesca da piramutaba (Brachyplatystoma vaillantii). $\mathrm{PhD}$ Thesis, State University of Campinas. 268pp. [In Portuguese].

Barthem, R.B. and Goulding, M. 1997. The Catfish Connection: Ecology, Migration, and Conservation of Amazon Predators. Columbia University, New York.

Best, R.C. and da Silva, V.M.F. 1993. Inia geoffrensis. Mammalian Species 426: $1-8$.
Borges, J.P., Gomes, M.C.R.L., Trindade, M.E.J., Cavalcante, D.P., Oliveira, J.A., Hercos, A.P., Zucchi, N., Lima, C.B., Pereira, S.A.P. and Queiroz, H.L. 2013. Influence of the hydrological cycle on physical and chemical variables of water bodies in the várzea areas of the middle Solimões river region (Amazonas, Brazil). Uakari 9: 33-47.

Botero-Arias, B., Franco, D.L. and Marmontel, M. 2014. A mortalidade de jacarés e botos associada à pesca da piracatinga na região do Médio Solimõesu.s. - Amazonas, Brasil. Instituto de Desenvolvimento Sustentável Mamairauá, Ministério da Ciência, Tecnologia e Inovação. 57pp. [In Portuguese]

Brazilian Ministry of the Environment. 2014. Listas das Espécies da Fauna Brasileira Ameaçadas de Extinção vigentes (Portarias MMA no. 444/ 2014 e no. 445/2014). Instituto Chico Mendes de Conservação da Biodiversidade, Brasília. [Available from: http://icmbio.gov.br; In Portuguese].

Buckland, S.T., Anderson, D.R., Burnham, K.P., Laake, J.L., Borchers, D.L. and Thomas, L. 2001. Introduction to Distance Sampling: Estimating Abundance of Biological Populations. Oxford University Press, New York, USA. vi $+\mathrm{xv}+432 \mathrm{pp}$.

Buckland, S.T., Anderson, D.R., Burnham, K.P., Laake, J.L., Borchers, D.L. and Thomas, L. (eds.) 2004. Advanced Distance Sampling. Oxford University Press, Oxford. 434pp.

da Silva, V.M.F. 1994. Aspects of the biology of the Amazonian dolphins, Inia geoffrensis de Blainville, 1817 (Cetacean, Iniidae) and Sotalia fluviatilis Gervais, 1853 (Cetacea, Delphinidae). PhD thesis, University of Cambridge. 327pp.

da Silva, V., Trujillo, F., Martin, A., Zerbini, A.N., Crespo, E., Aliaga-Rossel, E. and Reeves, R. 2018. Inia geoffrensis. The IUCN Red List of Threatened Species 2018: e.T10831A50358152. [Available from: http://www. iucnredlist.org; downloaded on 25 November 2018].

Fernandes, C.C. 1997. Lateral migration of fishes in Amazon floodplains Ecol. Freshw. Fish. 6: 36-44.

Gomez-Salazar, C., Trujillo, F., Portocarrero-Aya, M. and Whitehead, H. 2012a. Population, density estimates, and conservation of river dolphins (Inia and Sotalia) in the Amazon and Orinoco river basins. Mar. Mamm. Sci. 281: 124-53.

Gomez-Salazar, C., Trujillo, F. and Whitehead, H. 2012b. Ecological factors influencing group sizes of river dolphins (Inia geoffrensis and Sotalia fluviatilis). Mar. Mamm. Sci. 28: E124-E42.

Gómez, C., Trujillo, F., Diazgranados, M. and Alonso, J. 2008. Capturas dirigidas de delfines de río en la Amazonía para la pesca de mota (Calophysus macropterus): una problemática regional de gran impacto. pp.39-57. In: Trujillo, F., Alonso, J.C., Diazgranados, M.C. and Gómez, C. (eds). Fauna Acuática amenazada en la Amazonía Colombiana: análisis y propuestas para su conservación. Unión Gráfica, Colombia. 164pp. [In Spanish].

Goulding, M., Barthem, R.B. and Ferreira, E. 2003. The Smithsonian Atlas of the Amazon. Princeton Editorial Associates, Washington. $325 \mathrm{pp}$.

Hamilton, S.K. and Lewis, W.M. 1990. Physical characteristics of the fringing floodplain of the Orinoco River, Venezuela. Interciencia 15: 491-500.

Henderson, P.A. 1990. Fish of the Amazonian Igapo: Stability and conservation in a high diversity-low biomass system. J. Fish. Biol. 37: 61-66.

Herman, L.M., Vonfersen, L. and Solangi, M. 1996. The bufeo Inia geoffrensis in the Rio Lagarto Cocha of the Ecuadorian Amazon. Mar. Mamm. Sci. 12(1): 118-25.

Hoyt, E. 2005. Marine Protected Areas for Whales, Dolphins, and Porpoises: A World Handbook for Cetacean Habitat Conservation. Earthscan/James and James, London, UK. 477pp.

Hrbek, T., da Silva, V.M.F., Dutra, N., Gravena, W., Martin, A.R. and Farias, I.P. 2014. A new species of river dolphin from Brazil or: how little do we know our biodiversity. PloS One 9(1): e83623.

Iriarte, V. and Marmontel, M. 2013. Insights on the use of dolphins (boto, Inia geoffrensis and tucuxi, Sotalia fluviatilis) for bait in the piracatinga (Calophysus macropterus) fishery in the western Brazilian Amazon. J. Cetacean Res. Manage 13(2): 163-73.

Junk, W.J., Fernandez Piedade, M.T., Schöngart, J. and Wittmann, F. 2012. A classification of major natural habitats of Amazonian white-water river floodplains (várzeas). Wetlands. Ecol. Manage 20(6): 461-75. DOI: 10.1007/s11273-012-9268-0.

Kasuya, T. and Kajihara, T. 1974. Ecology of dolphins in the Amazon and Orinoco systems. pp.7-11. In: Report of the Scientific Expedition on the La Plata and Amazon Dolphins. University of Tokyo, Tokyo. 93pp. [Available from the author].

Laake, J. and Borchers, D. 2004. Methods for incomplete detection at distance zero. pp.108-89. In: Buckland, S.T., Anderson, K.P., Burnham, K.P., Laake, J., Borchers, D. and Thomas, L. (eds). Advanced Distance Sampling. Oxford University Press, Oxford. 595pp. 
Layne, J.N. 1958. Observations on freshwater dolphins in the upper Amazon. J. Mammal. 39: 1-22.

Leatherwood, J.S. 1996. Distributional ecology and conservation status of river dolphins (Inia geoffrensis and Sotalia fluviatilis) in portions of the Peruvian Amazon. PhD thesis, Texas A \& M University, College Station, Texas. 233pp.

Lewis, W.M., Hamilton, S.K., Lasi, M.A., Rodriguez, M.A. and Saunders, J.F. 2000. Ecological determinism on the Orinoco floodplain. Bioscience 50: 681-92.

Martin, A.R. and da Silva, V.M.F. 2004. River dolphins and flooded forest: seasonal habitat use and sexual segregation of botos (Inia geoffrensis) in an extreme ocean environment. J. Zool. (Lond.) 263: 295-305.

Martin, A.R., da Silva, V.M.F. and Salmon, D.L. 2004. Riverine habitat preferences of botos (Inia geoffrensis) and tucuxis (Sotalia fluviatilis) in the Central Amazon. Mar. Mamm. Sci. 20(2): 189-200.

McGuire, T.L. 2002. Distribution and abundance of river dolphins in the Peruvian Amazon. PhD thesis, Texas A\&M University, College Station, Texas, USA. 254pp.

McGuire, T.L. and Wienemiller, K.O. 1998. Occurrence patterns, habitat associations and potential prey of the river dolphin, Inia geoffrensis, in the Cinaruco River, Venezuala. Biotropica 30: 625-38.

Meade, R.H. and Koehnken, L. 1991. Distribution of the river dolphin, Tonina Inia geoffrensis, in the Orinoco River Basin of Venezuela and Colombia. Intersciencia 16(6): 300-12. [In English with summaries in Spanish, English and Portuguese].

Mintzer, V.J., Martin, A.R., da Silva, V.M.F., Pine, W.E., Barbour, A.B., Lorenzen, K. and Frazer, T.K. 2013. Effect of illegal harvest on apparent survival of Amazon River dolphins (Inia geoffrensis). Biol. Cons. 158: 280-86.

New, L.F., Harwood, J., Thomas, L., Donovan, C., Clark, J.S., Hastie, G., Thompson, P.M., Cheney, B., Scott-Hayward, L. and Lusseau, D. 2013. Modelling the biological significance of behavioural change in coastal bottlenose dolphins in response to disturbance. Funct. Ecol. 27: 314-22.

National Research Council 2005. Marine Mammal Populations and Ocean Noise - Determining when Noise Causes Biologically Significant Effects. The National Academies Press, Washington DC. 142pp.

Pilleri, G. and Gihr, M. 1977. Observations on the Bolivian (Inia boliviensis d'Orbigny, 1834) and the Amazonian Bufeo (Inia geoffrensis Blainville, 1817) with description of a new subspecies (Inia geoffrensis humboldtiana). pp.11-76. In: Pilleri, G. (eds). Investigations on Cetacea. Brain Anatomy Institut, Berne, Switzerland.

Pirotta, E., Brookes, K.L., Graham, I.M. and Thompson, P.M. 2014. Variation in harbour porpoise activity in response to seismic survey noise. Biol. Lett. 10: 20131090.

Santos, G.M.A., Quaresma, A.C., Barata, R.R., Martins, B.M.L., Siciliano, S., Silva, J.S., Jr. and Emin-Lima, R. 2012. Etho-ecological study of the Amazon pink dolphin, Inia geoffrensis (Cetacea: Iniidade) and the dolphins of genus Sotalia (Cetacea: Delphinidae) in Guamá river, Amazonia. Mar. Biodivers. Rec. 5: 1-5.

Santos, L.C., Jr., Barbosa, Q.R. and Marmontel, M. 2014. 2014. Aspectos da mortalidade de golfinhos amazônicos através de carcaças encontradas na região de Tefé, Amazonas. Abstract presented to the $66^{\mathrm{a}}$ Reunião Anual da SBPC - Sociedade Brasileira para o Progresso da Ciência, July 2014 (unpublished). 1p. [Available from: www.sbpcnet.org.br/livro/66ra/ resumos/resumos/7263.htm].

Seber, G.A.F. 1982. The Estimation of Animal Abundance and Related Parameters. 2nd ed. Charles Griffin and Company Ltd., London. ixvii+654pp

Secchi, E. 2012. Sotalia fluviatilis. 2013 IUCN Red List of Threatened Species, Version 2013.2. [Available from: http://www.iucnredlist.org].

Sioli, H. 1984. The Amazon and its main affluents: Hydrography, morphology of the river courses, and river types. pp.127-66. In: Sioli, H. (eds). The Amazon: Limnology and Landscape Ecology of a Mighty Tropical River and its Basin. Dr, W. Junk Publishers, Dordrecht. 763pp.

Trujillo, F. 2000. Habitat use and social behaviour of the freshwater dolphin Inia geoffrensis (de Blainville 1817) in the Amazon and Orinoco basins. Doctoral Thesis, University of Aberdeen. 157pp.

Trujillo, F., Crespo, E., Van Damme, P.A. and Usma, J.S. 2010. The Action Plan for South American River Dolphins 2010-2020. WWF, Fundacion Omacha, WDS, WDCS, Solamac. Bogota, D.C., Colombia. 249pp.

Utreras, V. 1996. Estimación de la Abundancia, Aspectos Ecológicos y Etológicos del Delfin Amazónico Inia geoffrensis (Cetacea: Iniidae) en el Rio Lagartococha, Amazonia Ecuatoriana. BSc Thesis, Pontificia Universidad Católica del Ecuador. 101pp. [In Spanish].

Vidal, O., Barlow, J., Hurtado, L.A., Torre, J., Cendón, P. and Ojeda, Z. 1997. Distribution and abundance of the Amazon river dolphin (Inia geoffrensis) and the tucuxi (Sotalia fluviatilis) in the upper Amazon River. Mar. Mamm. Sci. 13(3): 427-45. 